\title{
(2) OPEN ACCESS \\ Diabetic ketoacidosis with acute severe hypertriglyceridaemia-induced pancreatitis as first presentation of type 2 diabetes
}

\author{
Man Tek Kong $\odot$, ${ }^{1}$ Monica Pon Nunes, ${ }^{1}$ Kan Fat Leong ${ }^{2}$
}

1 Internal Medicine, Centro Hospitalar Conde de São Januário, Macau, China ${ }^{2}$ Intensive Care Unit, Centro Hospitalar Conde de São Januário, Macau, China

Correspondence to Dr Monica Pon Nunes; monicapon76@gmail.com

Accepted 25 March 2021

Check for updates

(c) BMJ Publishing Group Limited 2021. Re-use permitted under CC BY-NC. No commercial re-use. See rights and permissions. Published by BMJ.

To cite: Kong MT, Nunes MP, Leong KF. BMJ Case

Rep 2021;14:e239727.

doi:10.1136/bcr-2020-

239727

\section{SUMMARY}

Acute pancreatitis (AP) is an acute destructive inflammatory condition of the pancreas.

Hypertriglyceridaemia is the third most common worldwide cause of AP. Although the presentation of hypertriglyceridaemic pancreatitis (HTGP) is usually similar to other forms of AP, it may cause more severe AP and worse symptoms. Therefore, apart from the supportive care and treatment for $A P$, it is necessary to treat the underlying aetiology. There are no established guidelines for managing HTGP. Many treatment modalities have been reported, including intravenous insulin infusion, heparin and plasmapheresis. Randomised trials comparing their efficacy are lacking. Diabetic ketoacidosis (DKA) may be a risk factor for $A P$, but it is uncertain if AP triggers DKA or vice versa. Here, we describe a case of a 44-year-old man who presented with DKA concurrent with acute severe HTGP as first manifestation of type 2 diabetes mellitus. He was successfully managed with supportive care and intravenous insulin infusion.

\section{BACKGROUND}

Acute pancreatitis (AP) is a common and acute destructive inflammatory condition of the pancreas. It is characterised by abdominal pain and elevated levels of pancreatic enzymes in the blood. Hypertriglyceridaemia (HTG) is the third most common worldwide cause of AP after gallstones and alcohol. ${ }^{1}$ Although the clinical presentation of hypertriglyceridaemic pancreatitis (HTGP) is usually similar to other forms of AP, it may cause more severe AP and worse symptoms. ${ }^{2}$ HTG is considered a significant risk for AP when its levels are $>11.3 \mathrm{mmol} / \mathrm{L}$ $(1000.9 \mathrm{mg} / \mathrm{dL})$. As triglyceride levels increase, the incidence of AP also increases. ${ }^{3}{ }^{4}$ The initial management plan of patients with HTGP includes supportive care and treatment of AP, such as fluid resuscitation, pain control and nutritional support. Additional therapy to reduce the serum triglyceride levels is also very important to prevent lifethreatening complications. There are no established guidelines for managing HTGP. Insulin therapy has previously been used in these patients with promising outcomes. ${ }^{5}$

\section{CASE PRESENTATION}

A 44 -year-old man presented to our emergency department (ED) on 10 March 2020 with constant upper abdominal pain for 8 days. The pain radiated to the back for 3 days and was accompanied by anorexia and nausea. He was afebrile and denied any other related symptoms. He has a history of arterial hypertension that was well controlled with losartan $50 \mathrm{mg}$ daily and regular follow-up by a general practitioner. He smoked cigarettes for 20 years, about one pack daily. He denied alcohol or illicit drug use. He was married and worked as a chef. His family history was not relevant.

On arrival at the ED, he was alert, oriented and cooperative. His vital signs were: temperature of $37.1^{\circ} \mathrm{C}$, blood pressure of $135 / 74 \mathrm{~mm} \mathrm{Hg}$, respiratory rate of $21 / \mathrm{min}$ and pulse rate of $98 / \mathrm{min}$. His weight was $79 \mathrm{~kg}$, height $165 \mathrm{~cm}$ (body mass index $29 \mathrm{~kg} / \mathrm{m}^{2}$ ). The cardiopulmonary auscultation was normal, abdomen examination revealed tenderness in the epigastric region, no hepatosplenomegaly or masses. Bowel sounds were present and normal. Neurological examination was unremarkable.

The relevant laboratory results at the time of admission are provided in tables 1 and 2 . The serum was lipaemic on gross examination as shown in figure 1. Laboratory parameters were remarkable for high anion gap metabolic acidosis with uncompensated respiratory alkalosis, HTG, hyperglycaemia, markedly elevated serum lipase levels and urine ketones positive. Serum electrolytes, liver and renal function tests, coagulation profile and lactate dehydrogenase were within normal limits. Chest X-ray and abdominal X-ray were normal. An abdominal CT was performed and demonstrated an enlargement of the the distal pancreatic body and tail with blurred contour and peripancreatic fluid collection; focal hypodense area was found in the pancreatic tail. These findings were suggestive of $\mathrm{AP}$, with necrosis in the pancreatic tail (figure 2). There was no evidence of gallstones.

Based on the evidence of the clinical findings, laboratory and radiological investigations, the patient was diagnosed with HTGP and diabetic ketoacidosis (DKA). Thus, he was admitted to the medical intensive care unit for fluid resuscitation, pain control, bowel rest and intravenous insulin infusion therapy for both HTGP and DKA. The intravenous insulin infusion regimen we used was the DKA insulin therapy protocol. The insulin infusion was initiated at a rate of 0.1 units $/ \mathrm{kg} / \mathrm{hour}$ and was titrated for target a reduction of capillary blood glucose by $3.0 \mathrm{mmol} / \mathrm{L} /$ hour, a rise of the venous bicarbonate by $3.0 \mathrm{mmol} / \mathrm{L} /$ hour and a maintenance of serum potassium between 4.0 and $5.5 \mathrm{mEq} / \mathrm{L}$. After 1 day of intravenous insulin infusion therapy, his metabolic acidosis resolved and triglyceride level 


\begin{tabular}{|c|c|c|c|}
\hline Laboratory parameters & Specimen & Patient's result & Reference range \\
\hline White cell count & Serum & 19.5 & $4.3-10 \times 10^{9} / \mathrm{L}$ \\
\hline Haemoglobin & Serum & 170 & $135-170 \mathrm{~g} / \mathrm{L}$ \\
\hline Haematocrit & Serum & 45.6 & $41.0 \%-53 \%$ \\
\hline Platelets & Serum & 249 & $100-400 \times 10^{9} / \mathrm{L}$ \\
\hline Triglyceride & Serum & 136.4 & $<1.7 \mathrm{mmol} / \mathrm{L}$ \\
\hline Cholesterol & Serum & 30 & $<5.2 \mathrm{mmol} / \mathrm{L}$ \\
\hline Haemoglobin A1c ( $\mathrm{HbA1C})$ & Serum & 13.1 & $4.0 \%-6.0 \%$ \\
\hline Random blood glucose & Serum & 13.45 & $2.50-7.00 \mathrm{mmol} / \mathrm{L}$ \\
\hline $\mathrm{C}$ reactive protein & Serum & 7.22 & $<0.5 \mathrm{mg} / \mathrm{dL}$ \\
\hline Serum total amylase & Serum & 863 & $28-100 \mathrm{U} / \mathrm{L}$ \\
\hline Serum lipase & Serum & 2323 & $13-60 \mathrm{U} / \mathrm{L}$ \\
\hline Creatinine & Serum & 105 & $59-104 \mu \mathrm{mol} / \mathrm{L}$ \\
\hline Urea & Serum & 8.7 & $2.1-7.1 \mathrm{mmol} / \mathrm{L}$ \\
\hline Ketone & Urine & $>150$ & Negative \\
\hline
\end{tabular}

downtrended from $136.4 \mathrm{mmol} / \mathrm{L}$ to $11.58 \mathrm{mmol} / \mathrm{L}(12081 \mathrm{mg} /$ $\mathrm{dL}$ to $1025.7 \mathrm{mg} / \mathrm{dL}$ ). The intravenous insulin infusion therapy with $5 \%$ dextrose was continued with monitoring serum glucose every 1-2 hours, triglyceride every 24 hours and electrolytes monitoring every 12 hours. The insulin infusion therapy was stopped on day 4 when there was clinical improvement and the triglyceride level had decreased to $5.3 \mathrm{mmol} / \mathrm{L}(469.4 \mathrm{mg} / \mathrm{dL})$ (figure 3).

\section{OUTCOME AND FOLLOW-UP}

He was transferred from the medical intensive care unit to the general surgical ward after clinical improvement. He resumed oral feeding that was well tolerated. He was started on atorvastatin $40 \mathrm{mg}$ daily, fenofibrate $160 \mathrm{mg}$ daily and insulin therapy for diabetes and hyperlipidaemia control. He was discharged to follow-up by internal medicine consultation. At the 1-month follow-up, the patient showed complete recovery of the symptoms with serum triglyceride level decreased to 3.37 $\mathrm{mmol} / \mathrm{L}(298.5 \mathrm{mg} / \mathrm{dL})$. The control abdominal CT showed improvement of the distal pancreatic body and tail findings, and decrease in the volume of the peripancreatic fluid collection compared with the initial CT study. No new lesion was found in the pancreas and the peripancreatic region. At the 4-month follow-up, the patient's serum triglyceride level decreased to $2.53 \mathrm{mmol} / \mathrm{L}(223.89 \mathrm{mg} / \mathrm{dL})$ and haemoglobin A1c (HbA1c) to $12.9 \%$. His glycaemia is being controlled with diet control, Humalog Mix (mixture of insulin lispro and insulin lispro protamine), metformin and empagliflozine, still under adjustment for better diabetes and hyperlipidaemia control. His insulin and C

Table 2 Initial arterial blood gas results of the patient with respective reference ranges.

\begin{tabular}{lcl}
\hline Arterial blood gas & Patient's result & Reference range \\
\hline $\mathrm{pH}$ & 7.267 & $7.35-7.45$ \\
$\mathrm{PaO}_{2}$ & 92.1 & $80-100 \mathrm{~mm} \mathrm{Hg}$ \\
$\mathrm{PaCO}_{2}$ & 24.7 & $35-45 \mathrm{~mm} \mathrm{Hg}$ \\
$\mathrm{Base}_{2}$ excess (BE) & -15.7 & -2 to $2 \mathrm{mmol} / \mathrm{L}$ \\
$\mathrm{CHCO}_{3}$ & 9.5 & $22-26 \mathrm{mmol} / \mathrm{L}$ \\
Anion gap & 21.5 & $8-16 \mathrm{mmol} / \mathrm{L}$ \\
Lactate & $0.7 \mathrm{mmol} / \mathrm{L}$ & - \\
\hline
\end{tabular}

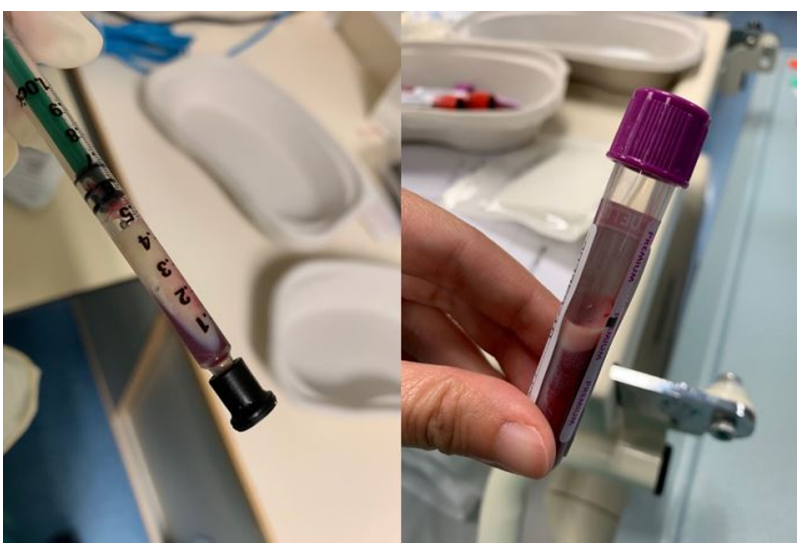

Figure 1 The blood sample was lipaemic on gross examination.

peptide level were normal. Unfortunately, the patient has missed follow-up for several months already.

\section{DISCUSSION}

AP is an inflammatory condition of the pancreas characterised by abdominal pain and elevated levels of pancreatic enzymes in the blood. Pancreatic duct and acinar injuries, by direct or indirect toxicity, impaired secretion and premature activation of digestive enzymes leading to autodigestion and acute inflammation. HTG is an important cause of acute AP. ${ }^{1}$ HTGP may cause more severe AP and worse symptoms. ${ }^{2}$ Thus, early clinical recognition of HTGP is important to provide appropriate therapy. The exact pathogenesis of HTGP is not fully understood. However, there have been a number of hypothesis relating to HTG. Triglycerides themselves do not appear to be toxic. The excess of triglycerides are subsequently hydrolysed by pancreatic lipases to release free fatty acids (FFAs). This releases high levels of FFAs that exceed the binding capacity of plasma albumin. These unbound FFAs self-aggregate into micellar structures with detergent properties. These toxic structures can cause damage to platelets, vascular endothelium and acinar cells, which result in ischaemia and acidosis which further worsens the FFA toxicity. ${ }^{67}$ Furthermore, excess serum triglycerides also increase the blood viscosity. Hyperviscosity leads to capillary plugging and impairs the vascular flow to the pancreas. This blockage can also increase the acidity of the pancreas, which predisposes the pancreas to acute inflammation through activation of trypsinogen. ${ }^{67}$

The diagnosis of HTGP is the same as other aetiologies of AP, which is based on the revised Atlanta classification criteriapresence of two of the following three criteria: (1) acute onset of persistent, severe epigastric pain often radiating to the back, (2) elevation in serum lipase or amylase to three times or greater

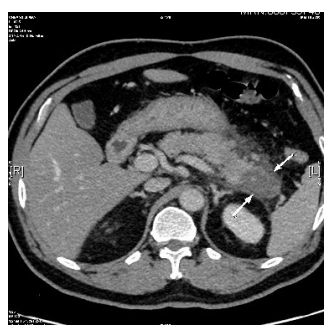

Figure $2 \mathrm{CT}$ abdomen showing the distal pancreatic body and tail are enlarged with blurred contour and peripancreatic fluid collection. A focal hypodense area is found in the pancreatic tail (arrows). Acute pancreatitis with necrosis in the pancreatic tail is suggested. 


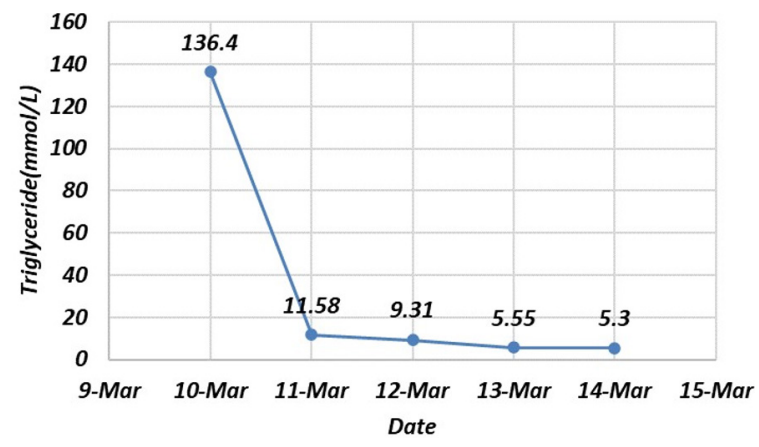

Figure 3 Curve indicating the changes in serum triglyceride levels during intravenous insulin infusion therapy.

than the upper limit of normal, and (3) characteristic findings of AP on imaging (contrast-enhanced CT, MRI or transabdominal ultrasonography). ${ }^{8}$ It can be difficult to identify HTG as the aetiology in AP. HTGP should be suspected in patients with AP and risk factors for HTG. Risk factors include poorly controlled diabetes, alcoholism, obesity, pregnancy, prior pancreatitis and a personal or family history of HTG. ${ }^{9-12}$ Serum triglyceride levels $>11.2 \mathrm{mmol} / \mathrm{L}(992 \mathrm{mg} / \mathrm{dL})$ are required for HTG to be considered the underlying aetiology of $\mathrm{AP}^{3}$

DKA may be a risk factor for AP, but it is uncertain if AP triggers DKA or vice versa. In patients with type 1 diabetes, decreased insulin production results in a marked reduction in lipoprotein lipase activity, which leads to HTG. Hyperinsulinaemia and insulin resistance in patients with type 2 diabetes enhances triglyceride production and decreases plasma triglyceride clearance. ${ }^{10}$ On the contrary, HTGP results in acute beta cell dysfunction, causing transient insulin deficiency and also increase in insulin resistance due to systemic inflammation, thus possibly triggering DKA. ${ }^{13}$ In our case report, the patient had annual check-up in a private clinic and had no previous history of dyslipidaemia. His initial blood test showed highly elevated HbA1c (13.1\%, normal range 4.0\%-6.0\%). Thus, DKA was considered to be the primary trigger.

There are no established guidelines for managing HTGP. The initial treatment should adhere to the practice recommendations as established for AP, including fluid resuscitation, analgesic treatment and bowel rest. Following this initial conservative management, it is necessary to rapidly reduce the level of serum triglycerides. Many treatment modalities have been reported, including intravenous insulin infusion, heparin and plasmapheresis. Randomised trials comparing their efficacy are lacking. Intravenous insulin infusion therapy has previously been used in these patients with promising outcomes to decrease serum triglyceride. ${ }^{5}$ The mechanism by which insulin lowers the level of serum triglycerides is by enhancing lipoprotein lipase activity,

Learning points

- Diabetic ketoacidosis (DKA) may be a risk factor for acute pancreatitis (AP), but it is uncertain if AP triggers DKA or vice versa.

- Hypertriglyceridaemic pancreatitis (HTGP) may cause more severe AP and worse symptoms. Rapidly reducing the level of serum triglycerides is important.

- Intravenous insulin infusion therapy is a safe and effective treatment option with promising outcomes in controlling acutely severe HTGP while treating DKA. an enzyme that accelerates chylomicron and very low-density lipoprotein metabolism to glycerol and FFAs. ${ }^{14} 15$ Therefore, it ultimately decreases the serum triglyceride levels. Because HTGP often presents in patients with uncontrolled diabetes, insulin can concurrently control hyperglycaemia in these patients. Studies have reported that insulin therapy can lower triglyceride levels to less than $5.6 \mathrm{mmol} / \mathrm{L}(496 \mathrm{mg} / \mathrm{dL})$ over 3-4 days. ${ }^{16}{ }^{17}$ Alternatively, in patients with HTGP presenting with one or more worrisome features, such as signs of hypocalcaemia, lactic acidosis, signs of worsening systemic inflammation or signs of worsening organ dysfunction or multiorgan failure, initial therapy with therapeutic plasma exchange is recommended. ${ }^{18}$

\section{Conclusion}

The presentation of DKA concurrent with acutely severe HTGP as first presentation of type 2 diabetes mellitus is extremely rare. There is no established guideline for the treatment of HTGP. In our case, we successfully managed acutely severe HTGP while treating DKA with intravenous insulin infusion as reported by other authors, supporting once more the safety of this therapeutic option.

Acknowledgements We would like to express our grattitude to Dr. Ng Hou, Chief Doctor of Internal Medicine Department for his support. Assistance provided by Dr. Alberto Mello e Silva was greatly appreciated.

Contributors Dr Man Tek Kong took care of the patient during his admission in the Intensive Care Unit and is the lead author of this case report. Dr Monica Pon follows up and treats the patient in Internal Medicine outpatient department. She gave guidance to write the case report and is the correspondance author of this case report. Dr Kan Fat Leong was the responsible doctor during the patient's admission in the Intensive Care Unit.Dr Hou Ng is the chief physician of Internal Medicine.

Funding The authors have not declared a specific grant for this research from any funding agency in the public, commercial or not-for-profit sectors.

Competing interests None declared.

Patient consent for publication Obtained

Provenance and peer review Not commissioned; externally peer-reviewed.

Open access This is an open access article distributed in accordance with the Creative Commons Attribution Non Commercial (CC BY-NC 4.0) license, which permits others to distribute, remix, adapt, build upon this work non-commercially, and license their derivative works on different terms, provided the original work is properly cited and the use is non-commercial. See: http://creativecommons.org/ licenses/by-nc/4.0\%.

ORCID iD

Man Tek Kong http://orcid.org/0000-0003-3622-9977

\section{REFERENCES}

1 Hammond DA, Finlay L. Treatment of Hypertriglyceridemia-Induced acute pancreatitis with insulin, heparin, and gemfibrozil: a case series. Hosp Pharm 2017;52:675-8.

2 Wan J, He W, Zhu Y, et al. Stratified analysis and clinical significance of elevated serum triglyceride levels in early acute pancreatitis: a retrospective study. Lipids Health Dis 2017;16:124.

3 Berglund L, Brunzell JD, Goldberg AC, et al. Evaluation and treatment of hypertriglyceridemia: an endocrine Society clinical practice guideline. J Clin Endocrinol Metab 2012;97:2969-89.

4 Joury A, Alshehri M, Mahendra A, et al. Therapeutic approaches in hypertriglyceridemia-induced acute pancreatitis: a literature review of available therapies and case series. J Clin Apher 2020;35:131-7.

5 Inayat F, Zafar F, Riaz I, et al. Hypertriglyceridemic pancreatitis: is insulin monotherapy a feasible therapeutic option? Cureus 2018:10:e3461.

6 de Pretis N, Amodio A, Frulloni L. Hypertriglyceridemic pancreatitis: epidemiology, pathophysiology and clinical management. United European Gastroenterol J 2018;6:649-55.

7 Kimura W, Mössner J. Role of hypertriglyceridemia in the pathogenesis of experimental acute pancreatitis in rats. Int J Pancreatol 1996;20:177-84.

8 Banks PA, Bollen TL, Dervenis C, et al. Classification of acute pancreatitis--2012: revision of the Atlanta classification and definitions by international consensus. Gut 2013;62:102-11. 
9 Fortson MR, Freedman SN, Webster PD. Clinical assessment of hyperlipidemic pancreatitis. Am J Gastroenterol 1995;90:2134-9.

10 Yadav D, Pitchumoni CS. Issues in hyperlipidemic pancreatitis. J Clin Gastroenterol 2003:36:54-62.

11 Chang CC, Hsieh YY, Tsai HD, et al. Acute pancreatitis in pregnancy. Zhonghua Yi Xue Za Zhi 1998:61:85-92.

12 Scherer J, Singh VP, Pitchumoni CS, et al. Issues in hypertriglyceridemic pancreatitis: an update. J Clin Gastroenterol 2014:48:195-203.

13 Reghina AD, Craciun S, Fica S. Severe transient hyperglycemia in a prediabetic patient during mild acute pancreatitis. Case Rep Med 2015;2015:1-3.

14 Flier JS, Underhill LH, Eckel RH. Lipoprotein lipase. New England Journal of Medicine 1989:320:1060-8
15 Goldberg IJ. Lipoprotein lipase and lipolysis: central roles in lipoprotein metabolism and atherogenesis. J Lipid Res 1996;37:693-707.

16 Mikhail N, Trivedi K, Page C, et al. Treatment of severe hypertriglyceridemia in nondiabetic patients with insulin. Am J Emerg Med 2005;23:415-7.

17 Tamez-Pérez HE, Sáenz-Gallegos R, Hernández-Rodríguez K, et al. [Insulin therapy in patients with severe hypertriglyceridemial. Rev Med Inst Mex Seguro Soc 2006;44:235-7.

18 Gelrud A, Whitcomb D C. Hypertriglyceridemia-induced acute pancreatitis, 2021. Available: https://www.uptodate.com/contents/hypertriglyceridemia-inducedacute-pancreatitis?search=Hypertriglyceridemia-\%20Induced\%20Pancreatitis\& sectionRank=1\&usage_type=default\&anchor=H7\&source=machineLearning\& selectedTitle=1 150\&display_rank=1\#H1024986038 [Accessed 15 Feb 2021]

Copyright 2021 BMJ Publishing Group. All rights reserved. For permission to reuse any of this content visit

https://www.bmi.com/company/products-services/rights-and-licensing/permissions/

BMJ Case Report Fellows may re-use this article for personal use and teaching without any further permission.

Become a Fellow of BMJ Case Reports today and you can:

- Submit as many cases as you like

Enjoy fast sympathetic peer review and rapid publication of accepted articles

- Access all the published articles

Re-use any of the published material for personal use and teaching without further permission

Customer Service

If you have any further queries about your subscription, please contact our customer services team on +44 (0) 2071111105 or via email at support@bmj.com.

Visit casereports.bmj.com for more articles like this and to become a Fellow 